\title{
Neuropharmacological Evaluation of Areca catechu on Chronic Unpredictable Mild Stress Model of Depression in Mice: Behavioral and Biochemical Evidences
}

Uday Kumar Goud*, Kshema Hasanthi, Kavya Pandiri, Kandavalli Manipriya

Department of Pharmacology, G. Pulla Reddy College of Pharmacy, Osmania University, Hyderabad, Telangana, India - 500028.

\section{ABSTRACT}

Erratic chronic stresses can lead to the state identical to mental anxiety. The impact of free radicals in the pathogenesis of stress-induced depression is significant. Arecoline alkaloid found in kernels of the Areca catechu seeds, has wide spectrum of biological and pharmacological activities. The objective of this research was to evaluate the protective effect of Areca catechu on chronic unpredictable mild stress prompted variations in behavioral and brain oxidative stress parameters in mice. Areca catechu nuts' antidepressant effect could well be attributed to the alkaloids and saponins found in them, according to physicochemical research. For a period of 2 weeks, the animals were acclimatized and their baseline sucrose preference test was performed. At the termination of the study period, all the animal were exposed to behavioral and biochemical tests. The aqueous extract of Areca catechu nut displayed significant antidepressant activity by forced swim test that was additionally established by the inviolate locomotor actions of animals in the open field and actophotometer activity. Finally, it was concluded that the increase of serotonin and noradrenaline in the areca nut may have an antidepressant impact in chronic unpredictable mild stress.

Keywords: Areca catechu, alkaloids, chronic unpredictable mild stress, forced swim test, lipid peroxidation, antioxidants.

\section{INTRODUCTION}

As per the World Health Organization (WHO), depression is a severe illness that is one of the major risk factors globally. Chronic stress is a well-known cause or a consequence of a variety of psychiatric disorders in humans, particularly severe depression. ${ }^{1}$ According to epidemiological analysis, stress is caused by the interaction of several genes with the surroundings or other variables. As per the monoamine theory, depression is caused by a lack of monoaminergic transmission in the central nervous system, while mania is caused by an overabundance.2,3 Feeling of deep hopelessness and sorrow, psychological retardation and inability to focus, gloomy anxiety, lack of enjoyment, self-deprecation, and fluctuating anger or aggressiveness are all symptoms of major depression. Physical alterations include insomnia or hypersomnia; changed eating behaviors, including anorexia and losing weight or occasionally overeating; reduced energy and libido; and disturbance of the usual

*Corresponding Author: gadipalligoud@gmail.com

Received: 22 March 2021

Revised: 15 April 2021

Accepted: 20 April 2021 (C)2020. Open access. This article is distributed under the terms of the Creative Commons Attribution-Noncommercial-Share Alike 4.0 Unported License. 
circadian and ultradian cycles of activities, body temperature, and altered endocrine processes. ${ }^{4}$

Tricyclic antidepressants, noradrenergic reuptake inhibitors, selective serotonin reuptake inhibitors, and other atypical antidepressant medications like monoamine oxidase inhibitors are presently accessible as pharmacological treatments for depression.5,6 Yet, antidepressant effect is typically uneven, and most of them have unpleasant side effects including drowsiness, apathy, weariness, as well as sleep disturbances, memory deficits, and infertility. As a result, there is still a great need for novel antidepressants that are both effective and well tolerated. ${ }^{7}$

Earlier studies has shown that frequent and unexpected stress has a substantial influence on the generation of reactive oxygen species (ROS) in the brain, which leads to oxidative damage and dysregulation in CNS. ${ }^{8}$ Numerous studies have shown that antioxidants have an essential role in alleviating chronic unpredictable mild stress caused (CUMS) depression, considering the aforesaid results.

Areca catechu (Arecaceae) is one of the most basic ingredients in Indian medicine. It grows on the arid plateaus of Southern India, Mysore, Malabar, Canara, and Assam. ${ }^{9}$ Polyphenolic compounds, saponins, tannins, alkaloids, and fibers are the main components of A. catechu. Catechu, gum, tannin, gallic acid, and alkaloids (choline, arecoline, arecaidine, arecaine, guvacine, guvacoline) are found in the kernels. (+)catechin, \& (-)epicatechin tetramers, along with procyandins A-1, B-1, and B-2 have been extracted from the seed of $A$. catechu. ${ }^{10,11}$ The herb was acclaimed for its therapeutic qualities, which included antibacterial and antiviral activities. Areca nut is a frequent component in betel quid, which also includes piper betel leaf and lime with or without tobacco. It has antioxidant, antihypertensive, hypoglycemic, platelet aggregation, anti-HIV, proteasome inhibitors, molluscicidal, anti-venom, oxytocic and anti-fertility activities. It affects brain to induce antidepressant, anticonvulsant, and CNS stimulant activities.9,12,13 The objective of this paper was to assess the impact of aqueous extract of $A$. catechu nut on chronic moderate stress-induced depression in mice.

\section{MATERIAL AND METHODS}

\subsection{Chemicals and Reagents}

Fluoxetine hydrochloride (Fludac) was supplied by Cadila Pharmaceuticals Ltd., India. Sigma Aldrich, Hyderabad, India provided the thiobarbituric acid (TBA) and trichloroacetic acid (TCA). Ellman's reagent, butanol, pyridine, hydrogen peroxide, EDTA, and other chemical were obtained from standard sources.

\subsection{Experimental Animal}

Swiss albino mice of either sex, weighing about 25-30 g, were used in this study. The animals were kept under conventional laboratory settings, which included a 12:12 hour light/dark cycle and a temperature of $22 \pm 2^{\circ} \mathrm{C}$ with a humidity of $60 \pm 10 \%$. The animals were fed a normal food and given free access to water, and were housed in clean polypropylene cages. They were split into experimental groups after a week of laboratory acclimatization. All experimental methods were carried out in compliance with the guidelines established by the committee for the regulation and supervision of animal research. The Institutional Animal Ethics Committee, G. Pulla Reddy College of Pharmacy (GPRCP/IAEC/23/19/ 02/PCI/AE-4-Mice-M/F-30), Hyderabad, India authorized the study.

\subsection{Collection and Extraction of Areca Nut}

A. catechu nuts were collected from local market of Coimbatore, Inida. The extract was made by combining $20 \mathrm{~g}$ of well rinsed and coarsely diced nuts with $100 \mathrm{ml}$ distilled water in a $250 \mathrm{ml}$ Erlenmeyer flask and boiling the liquid for 10 minutes. After then, the solution was withdrawn from the head source and allowed to cool to room temperature. The extract was then filtered by a Whatman filter paper No. 1 The extract was stored at $4^{\circ} \mathrm{C}$ in the refrigerator for future studies. ${ }^{14}$

\subsection{Qualitative Phytochemical Analysis}

Phytochemical components of the aqueous extracts of $A$. catechu nut (ACAE) and betel leaf 
were screened by using standard methods. The components analyzed were alkaloids, flavonoids, anthroquinone, saponins, phenol, protein, coumarin, reducing sugar, tannins, phytosterols, anthrocyanides, triterpinoids, phlobatannins, acids and glycosides. ${ }^{15}$

\subsection{Experimental Protocol}

Before beginning the Chronic Unpredictable Mild Stress (CUMS) regimen, the animals were acclimatized for one week and trained to consume a 1 percent $(\mathrm{w} / \mathrm{v})$ sucrose solution. A sucrose preference baseline test was done three days later. They are then separated into five groups $(n=6)$ at random.

Group I (Normal Control): Received vehicle for 14 days

Group II (Disease Control): Received CUMS + vehicle for 14 days

Group III (Standard Control): Received CUMS + 20 $\mathrm{mg} / \mathrm{kg}$ Fluoxetine $\mathrm{HCl}$ for 14 days

Group IV (Treatment I): Received CUMS + 10 $\mathrm{mg} / \mathrm{kg}$ ACAE for 14 days

Group V (Treatment II): Received CUMS + 20 $\mathrm{mg} / \mathrm{kg}$ ACAE for 14 days

Table 1: Schedule stressors to induce chronic unpredictable mild stress

\begin{tabular}{|c|c|c|c|}
\hline Days & $\begin{array}{l}\text { Schedule } \\
\text { Stressors }\end{array}$ & Days & $\begin{array}{l}\text { Schedule } \\
\text { Stressors }\end{array}$ \\
\hline $1-7$ & \multicolumn{3}{|l|}{ Adaptation } \\
\hline 8 & $\begin{array}{l}\text { Exposure to } \\
\text { empty water } \\
\text { bottles }\end{array}$ & 15 & $\begin{array}{l}\text { Immobilization } \\
\text { for } 2 \mathrm{hrs}\end{array}$ \\
\hline 9 & $\begin{array}{l}\text { Immobilization } \\
\text { for } 2 \text { hrs }\end{array}$ & 16 & $\begin{array}{l}\text { Exposure to } \\
\text { empty water } \\
\text { bottles }\end{array}$ \\
\hline 10 & $\begin{array}{l}\text { Overnight } \\
\text { illumination }\end{array}$ & 17 & $\begin{array}{l}\text { Overnight } \\
\text { illumination }\end{array}$ \\
\hline 11 & $\begin{array}{l}\text { Tail pinch for } \\
60 \mathrm{sec}\end{array}$ & 18 & $\begin{array}{l}\text { Tail pinch for } 30 \\
\text { sec }\end{array}$ \\
\hline 12 & $\begin{array}{l}\text { Exposure to } \\
\text { foreign object } \\
\text { for } 24 \mathrm{hrs}\end{array}$ & 19 & $\begin{array}{l}\text { Cage tilting at } 45^{\circ} \\
\text { for } 7 \mathrm{hrs}\end{array}$ \\
\hline 13 & $\begin{array}{l}\text { Cage tilting at } \\
45^{\circ} \text { for } 7 \mathrm{hrs}\end{array}$ & 20 & $\begin{array}{l}\text { Tail pinch for } 30 \\
\text { sec }\end{array}$ \\
\hline 14 & $\begin{array}{l}\text { Tail pinch for } \\
30 \mathrm{sec}\end{array}$ & 21 & $\begin{array}{l}\text { Exposure to } \\
\text { foreign object for } \\
24 \mathrm{hrs}\end{array}$ \\
\hline
\end{tabular}

On the $15^{\text {th }}$ day, all of the animals were exposed to different behavioral tests (Sucrose Preference, Forced Swim, Open Field, and Actophotometer
Tests) at the end of the treatment period. On the $15^{\text {th }}$ day, all of the animals were $\mathrm{CO}_{2}$ asphyxiated and their brains were dissected to determine endogenous antioxidant levels of MDA and GSH. ${ }^{16}$

\subsection{Induction of Chronic Unpredictable} Mild Stress (CUMS)

The mice were treated to CUMS as previously described, with minor modifications. Animals were exposed to stress paradigm once a day for two weeks, with the following stressors employed in the order (Table 1). ${ }^{17,18}$

\subsection{Behavioral Assessment}

\subsubsection{Body Weight Gain and Sucrose Consumption}

Sucrose (1\% sucrose solution) intake and weight gain were recorded once per week, following 18 hours of food and water restriction, during a 1hour interval. At the end of the test, the preweighed bottle was weighed to determine consumption. The consumption was measured in grams per kilogram of body weight $(\mathrm{g} / \mathrm{kg})$. Less than a week before CUMS began, the baseline was taken. The interval of fasting and restriction of food and drink prior to sucrose intake assessment might be viewed as an additional stress on top of the CUMS procedure. ${ }^{19}$

Sucrose Preference (\%)

$=\frac{\text { Sucrose Solution Intake }(\mathrm{g})}{\text { Sucrose Solution Intake }(\mathrm{g})+\text { Water Intake }(\mathrm{g})} \times 100$

\subsubsection{Forced Swim Test (FST)}

The FST swim test was carried out using Dhingra et al (2005) method. The mouse was taken in a beaker container of $22.5 \mathrm{~cm}$ diameter and $30 \mathrm{~cm}$ height with $15 \mathrm{~cm}$ of water level of $23 \pm 2^{\circ} \mathrm{C}$ temperature. The mice were submerged in water for 6 minutes and forced to swim. Each animal acquired a characteristic motionless position after a 2-minute period of intense exercise. When a mouse stayed afloat in water without moving, making just the smallest moves of its paws required to sustain its head above water, it was termed motionless. During the next 4 minutes of the 6-minute test, the total time of immobility was observed. Every animal was only used once. Between sessions, the water was replaced and the temperature was set at $23 \pm 2^{\circ} \mathrm{C} .{ }^{20}$ 


\subsubsection{Open Field Test}

The open field test was conducted before one day following the previous stressor and drug exposure. The exposed area was split into 25 (5x5 $\mathrm{cm})$ equal segments by white stripes $(20 \times 20 \mathrm{~cm})$, with a foundation of $100 \times 100 \mathrm{~cm}$ and black walls of $20 \mathrm{~cm}$. The squares were separated into two sectors: peripheral and central, with the center sector containing the 9 central squares $(3 \times 3 \mathrm{~cm})$ and the periphery sector containing the squares along the wall. For additional study, the animals were put in the center section and their activity was videotaped for 5 minutes. Across each test, the open field arena was completely cleaned. A faint crimson light illuminated the room. The animals were not exposed to any stressors for at least 24 hours before to the test. The action on the open field was manually scored. When the mice traversed a sector boundary with both hind limbs, it was given a score for mobility. During the 5minute test, peripheral activity i.e. the number of peripheral sectors crossed, central activity i.e. the number of center squares crossed, and total activity i.e. overall activity in the peripheral and central regions were all assessed. ${ }^{21}$

\subsubsection{Actophotometer Test}

Animal locomotor activity was measured using an actophotometer equipped with a digital counter, photocell, and light source. For 5 minutes, each animal was inserted in the Actophotometer, and the baseline activity score was measured for each animal. After 30 minutes and 1 hour, every animal was given the appropriate medication and an activity score was taken. The score of stopped activity was used as a measure of CNS depression. ${ }^{22}$

\subsection{Biochemical Assessment}

\subsubsection{Preparation of Tissue Homogenate}

In an ice cold state, $10 \mathrm{mg}$ of tissue was weighed and homogenized in $5 \mathrm{ml}$ ODF buffer solution using a remimotor at a speed of $2500 \mathrm{rpm}$ for 2 minutes.

\subsubsection{Estimation of Malondialdehyde (MDA)}

The amount of malondialdehyde in tissue is a marker of lipid peroxidation. Method of Ohkawa et al (1979) was used to assess it in brain tissue homogenate. Thiobarbituric acid (TBA) interacts with malondialdehyde (MDA) in an acidic medium at $95^{\circ} \mathrm{C}$ for 30 minutes to produce thiobarbituric acid reative product, which has a $534 \mathrm{~nm}$ absorbance. ${ }^{23}$

\subsubsection{Estimation of Reduced Glutathione (GSH)}

Ellman's technique was used to assay GSH. The disulfide chromogen 5,5-dithiobis (2-nitrobenzoic acid) (DTNB) was easily converted to a brightly yellow molecule by the sulfahydryl group of GSH. The decreased chromogen's absorbance was measured at $412 \mathrm{~nm}$ and was directly proportional to the GSH content. ${ }^{24}$

\subsection{Statistical Analysis}

All data was presented as a mean \pm standard error of the mean (SEM). Graph pad prism software was used to do a one-way analysis of variance (ANOVA) proceeded by a Tukey's post hoc test on the data (5.3 version). Statistical significance was defined as a value of $P<0.05$.

\section{RESULTS}

\subsection{Preliminary Phytochemical Analysis}

The ACAE revealed the presence of alkaloids, tannins, saponins, phenol, reducing sugar, triterpenoids, glycosides and gums.

\subsection{Effect on Sucrose Preference Test}

In the baseline test, no significant difference was observed in sucrose preference (\%) between any of the groups, as indicated in Table 2 . When the mice were exposed to stress for 14 consecutive days, their sucrose preference fell considerably $(P$ $<0.01$ ) when compared to the vehicle control group. When compared to disease control, ACAE $(10 \& 20 \mathrm{mg} / \mathrm{kg}$ ) and fluoxetine $(20 \mathrm{mg} / \mathrm{kg})$ significantly $(P<0.01 ; P<0.001)$ enhanced sucrose desire. When compared to normal control, however, these alterations were more severe than typical value.

\subsection{Effect on Duration of Immobility in FST}

When compared to the normal control group, mice given CUMS had significantly longer periods of immobility $(P<0.01)$. In contrast to the disease 
control animals, ACAE $(10 \& 20 \mathrm{mg} / \mathrm{kg})$ and fluoxetine significantly $(P<0.01)$ reduced the length of immobility (Table 2).

\subsection{Effect on Locomotor Activity in Open}

\section{Field Test}

When mice were given CUMS, the length of locomotor activity was significantly reduced $(P<$ 0.001) compared to the normal control group. When compared to disease control, ACAE $(10 \& 20$ $\mathrm{mg} / \mathrm{kg})$ and fluoxetine significantly $(P<0.01)$ increased the length of locomotor activity (Table 2).

\subsection{Effect on Locomotor Activity in Actoph- otometer Test}

When mice were given CUMS, the length of locomotor activity was significantly reduced $(P<$ 0.001) compared to the normal control group. When compared to the control group, the ACAE (10 \& $20 \mathrm{mg} / \mathrm{kg}$ ) and fluoxetine $(20 \mathrm{mg} / \mathrm{kg})$ treated groups exhibited substantial CNS antidepressant effects. This depression was, however, less severe in the $A$. catechu nut-treated group than in the fluoxetine-treated group (Table 2).

\subsection{Effect on Brain MDA Level}

In contrast to the normal control group, induction of CUMS significantly $(P<0.001)$ raised MDA levels in the brain. ACAE $(10 \& 20 \mathrm{mg} / \mathrm{kg})$ and fluoxetine $(20 \mathrm{mg} / \mathrm{kg})$ treatment significantly $(P<$ 0.01) decreased MDA levels (Table 3).

\subsection{Effect on Brain GSH Level}

In contrast to the normal control group, induction of persistent CUMS resulted in a significant $(P<$ 0.001 ) reduction in brain GSH concentration. In a dose-dependent manner, treatment with ACAE (10 \& $20 \mathrm{mg} / \mathrm{kg}$ p.o) and fluoxetine $(20 \mathrm{mg} / \mathrm{kg}$ p.o) dramatically enhanced reduced GSH in stressed mice when compared to illness control animals (Table 3).

\section{DISCUSSION}

The $\mathrm{GABA}_{A}$ receptor complex engaged in physiological functions related to behavioral, psychological and neurological disorders is primarily responsible for anxiety in the CNS. Oxidative stress is linked to depression, according to previous researches. ${ }^{25,26}$ The phytochemical analysis of ACAE resulted in the discovery of different components such as alkaloids, tannins, saponins, phenol, reducing sugar, triterpenoids, glycosides, and gums in the current study. The active principle underlying majority of the biological activity evoked by the nut has been attributed to arecoline alkaloid. ${ }^{27}$

Table 1: Effect of ACAE on various behavioral tests in mice

\begin{tabular}{|c|c|c|c|c|c|c|c|}
\hline \multirow[b]{2}{*}{ Groups } & \multicolumn{2}{|c|}{$\begin{array}{c}\text { Sucrose } \\
\text { Preference }(\%)\end{array}$} & \multirow{2}{*}{$\begin{array}{c}\text { Forced } \\
\text { Swim } \\
\text { Test (Sec) }\end{array}$} & \multirow[b]{2}{*}{$\begin{array}{l}\text { Actophotometer } \\
\text { Test (Count) }\end{array}$} & \multicolumn{3}{|c|}{ Open Field Test } \\
\hline & Before & After & & & $\begin{array}{c}\text { Peripheral } \\
\text { Square (Sec) }\end{array}$ & $\begin{array}{l}\text { Central } \\
\text { Square } \\
\text { (Sec) }\end{array}$ & $\begin{array}{c}\text { Central } \\
\text { Crossing's } \\
\text { (Count) }\end{array}$ \\
\hline $\begin{array}{l}\text { Normal } \\
\text { Control }\end{array}$ & $\begin{array}{c}38.59 \pm \\
6.27\end{array}$ & $\begin{array}{l}35 \pm \\
2.15\end{array}$ & $\begin{array}{c}161.5 \pm \\
14.58\end{array}$ & $338.5 \pm 5.14$ & $134.33 \pm 2.36$ & $\begin{array}{c}45.66 \pm \\
2.36\end{array}$ & $7.33 \pm 0.61$ \\
\hline $\begin{array}{l}\text { Disease } \\
\text { Control }\end{array}$ & $\begin{array}{c}49.79 \pm \\
5.61\end{array}$ & $\begin{array}{c}19.14 \pm \\
2.83^{\mathrm{b}}\end{array}$ & $\begin{array}{l}236 \pm \\
5.08^{c}\end{array}$ & $278 \pm 1.58^{c}$ & $163.5 \pm 2.37 \mathrm{c}$ & $\begin{array}{c}19.83 \pm \\
3.38^{c}\end{array}$ & $3 \pm 0.57 c$ \\
\hline $\begin{array}{l}\text { Standard } \\
\text { Control }\end{array}$ & $\begin{array}{c}44.44 \pm \\
10.38\end{array}$ & $\begin{array}{c}39.5 \pm \\
2.41^{* * *}\end{array}$ & $\begin{array}{c}109 \pm \\
6.093^{* *}\end{array}$ & $317.83 \pm 7.67^{* * *}$ & $\begin{array}{c}131.83 \pm \\
1.40^{* * *}\end{array}$ & $\begin{array}{c}49 \pm \\
1.13^{* * *}\end{array}$ & $\begin{array}{c}6.67 \pm \\
0.49^{* * *}\end{array}$ \\
\hline $\begin{array}{c}\text { Treatment } \\
\text { I }\end{array}$ & $\begin{array}{l}38.89 \\
\pm 5.93\end{array}$ & $\begin{array}{c}35.33 \pm \\
2.69^{* *}\end{array}$ & $\begin{array}{c}181.66 \pm \\
4.36^{* *}\end{array}$ & $304 \pm 4.13^{* *}$ & $\begin{array}{c}152.16 \pm \\
2.32^{*}\end{array}$ & $31 \pm 2.32^{*}$ & $5.16 \pm 0.31^{*}$ \\
\hline $\begin{array}{c}\text { Treatment } \\
\text { II }\end{array}$ & $\begin{array}{c}52.42 \pm \\
5.06\end{array}$ & $\begin{array}{c}37.49 \pm \\
2.16^{* *}\end{array}$ & $\begin{array}{c}175.83 \pm \\
3.31^{* * *}\end{array}$ & $310.5 \pm 5.23^{* * *}$ & $149 \pm 3.09^{* *}$ & $\begin{array}{c}36 \pm \\
0.87^{* *}\end{array}$ & $\begin{array}{l}5.83 \pm \\
0.48^{* *}\end{array}$ \\
\hline
\end{tabular}

Values were expressed as mean \pm SEM (n=6). Data were analyzed by one way ANOVA followed by Tukey's Test. ${ }^{b} P<0.01,{ }^{c} P<0.001$ when compared to the normal control group; ${ }^{* *} P<0.001,{ }^{* *} P<0.01,{ }^{*} P<0.05$ when compare to the disease control group. 
Table 3: Effect of ACAE on endogenous antioxidants in brain

Groups MDA (nmol MDA/mg protein)
GSH ( $\mu \mathrm{mol} / \mathrm{mg}$ protein)

\begin{tabular}{ccc} 
Normal Control & $1.73 \pm 0.16$ & $0.25 \pm 0.03$ \\
\hline Disease Control & $3.90 \pm 0.26^{\mathrm{c}}$ & $0.08 \pm 0.02^{\mathrm{c}}$ \\
\hline Standard Control & $2.40 \pm 0.26^{* *}$ & $0.24 \pm 0.03^{* * *}$ \\
\hline Treatment I & $2.90 \pm 0.25^{* *}$ & $0.21 \pm 0.02^{* *}$ \\
\hline Treatment II & $2.70 \pm 0.21^{* *}$ & $0.22 \pm 0.04^{* *}$
\end{tabular}

Values were expressed as mean \pm SEM (n=6). Data were analyzed by one way ANOVA followed by Tukey's Test. ${ }^{c} P<0.001$ when compared to the normal control group; ${ }^{* *} P<0.001,{ }^{* *} P<0.01$, when compare to the disease control group.

Treatment with ACAE reduces unpredictable chronic depression produced by mild stress in the current investigation, resulting in a shorter period of immobility as shown by higher sucrose intake, the forced swim test, and the oxidative stress measure. According to earlier studies, animals who were exposed to diverse stress conditions for 14 days acquired substantial depression symptoms. The administration of uncontrolled stressors is a sound animal paradigm for the preclinical assessment of antidepressants. ${ }^{31}$ In earlier studies, the FST test and sucrose preference test were utilized to characterize CUMS-induced depressed behavior in mice. ${ }^{28}$

In a mouse model, the sucrose preference test is a useful and reliable behavioral indication of chronic stress. Sucrose preference is thought to be a sign of loss of interest or pleasure, which is a fundamental symptom of depression. Chronic unexpected stress, according to the research, destroys nerve cells in the neuronal system. The serotonergic and dopaminergic systems are considered to be damaged; resulting in a lack of capacity to perceive happiness. ${ }^{29}$ In the current research, anxious mice consumed a smaller amount of sucrose solution than unstressed mice. This results supports prior reports that mice subjected to CUMS consumed not as much of sucrose than non-stressed mice, but treatment with ACAE and fluoxetine dramatically restores sucrose preference. ${ }^{30}$ Reduced sucrose preference indicates $A$. catechu antidepressant-like effect. In the depression model of CUMS, catechu nut is used. Antidepressant therapy has been demon- strated in studies to be effective in reversing the chronic stress-induced decrease in sucrose intake. $^{31}$

In the current study, the CUMS group had a longer period of immobility in FST, indicating a depressive-like condition. In FST, immobility is a sign of depression. Treatment with ACAE significantly improved sucrose preference and decreased immobility time in mice in the CUMS group, which was consistent with previous studies. ${ }^{32}$ The effectiveness of $A$. catechu nut were equivalent to those of fluoxetine.

An open field test and an actophotometer were used to determine anxiety levels. In an open field test, ACAE therapy was shown to successfully counteract CUMS-induced increases in actophotometer count and decreased crossing and rearing numbers. Bende and colleagues (2016) also found that continuous treatment of $A$. catechu nut extract improved depressive symptoms, indicating that it has a neuroprotective impact. ${ }^{33}$

The development of neuropsychiatric diseases is influenced by reactive oxygen species (ROS). Increased generation of ROS can result in destruction of macromolecules such as DNA, proteins, and lipids, resulting in neuronal malfunction and depression. The antioxidant state of brain tissue was shown to be impaired by CUMS, probably due to the generation of increased ROS. ${ }^{34-37}$ Other investigations have corroborated this finding. Because they recovered to normal ranges after antidepressant therapy, antioxidant enzymes and lipid peroxidation may be state indicators of severe depression. ${ }^{38}$ Malondialdehy- 
de, a by-product of lipid peroxidation, increased after 14 days of exposure to many stressors in the current investigation. Treatment with repeated ACAE extract prevented lipid peroxidation and CUMS-induced depressive-like behavior.

GSH is a non-enzymatic intracellular thiol antioxidant that helps to neutralize free radicals. Depressive-like behavior was produced by a decrease in antioxidant defense mechanisms. ${ }^{39}$ In the CUMS model of depression, stressed mice exhibit decreased brain GSH levels, indicating a change in antioxidant brain defenses. The GSH level in the brains of stressed mice was recovered after treatment with ACAE. Similarly, earlier research have indicated that phytochemicals such as curcumin, punarnavine, mucunapruriens, and piperment have a protective effect against CUMSinduced depression by correcting behavioral and biochemical characteristics. ${ }^{40-43}$

\section{CONCLUSION}

Finally, the results of this investigation showed that treatment with an aqueous extract of $A$. catechu nut have protective effect against chronic mild stress-induced depression. The active components of areca nut extract, more probably alkaloid and saponin, evoked dose-dependent antianxiety and antidepressant action, which can be ascribed to atypical increase of serotonin and noradrenaline levels in the hippocampus of mice. As a result, Areca catechu can be utilized as an antioxidant and neuroprotective agent.

Acknowledgement: The authors are grateful to Dr. B. Veeresh, HOD, Department of Pharmacology, G. Pulla College of Pharmacy, Osmania University, Hyderabad, Telangana, India for his support during this research work.

Conflict of Interest: The authors revealed no conflict of interest.

Source of Support: The study received no funding from any source.

\section{REFERENCES}

1. Kessler RC, Berglund P, Demler O, Jin R, Koretz D, Merikangas KR, Rush AJ, Walters EE, Wang PS;
National Comorbidity Survey Replication. The epidemiology of major depressive disorder: results from the National Comorbidity Survey Replication (NCS-R). JAMA. 2003 Jun 18;289(23):3095-105.

2. Lohoff FW. Overview of the genetics of major depressive disorder. Curr Psychiatry Rep. 2010 Dec;12(6):539-46.

3. Delgado PL. Depression: the case for a monoamine deficiency. J Clin Psychiatry. 2000;61 Suppl 6:7-11.

4. Tondo L, Isacsson L, Baldesssarini RJ. Suicidal behavior in bipolar disorder: Risk and prevention. CNS Drugs 2003;17:491-511.

5. Gautam S, Jain A, Gautam M, Vahia VN, Grover S. Clinical Practice Guidelines for the management of Depression. Indian J Psychiatry. 2017 Jan;59(Suppl 1):S34-S50.

6. Huang YJ, Lane HY, Lin CH. New Treatment Strategies of Depression: Based on Mechanisms Related to Neuroplasticity. Neural Plast. 2017:4605971.

7. Ferguson JM. SSRI Antidepressant Medications: Adverse Effects and Tolerability. Prim Care Companion J Clin Psychiatry. 2001 Feb;3(1):22-27.

8. Nemeroff CB. The burden of severe depression: a review of diagnostic challenges and treatment alternatives. J Psychiatr Res. 2007 Apr-Jun;41(34):189-206.

9. Peng $\mathrm{W}$, Liu YJ, Wu N, Sun T, He XY, Gao YX, Wu CJ. Areca catechu L. (Arecaceae): a review of its traditional uses, botany, phytochemistry, pharmacology and toxicology. J Ethnopharmacol. 2015 Apr 22;164:340-56.

10. Jain V, Garg A, Parascandola M, Chaturvedi P, Khariwala SS, Stepanov I. Analysis of Alkaloids in Areca Nut-Containing Products by Liquid Chromatography-Tandem Mass Spectrometry. J Agric Food Chem. 2017 Mar 8;65(9):1977-1983.

11. Yuan M, Ao Y, Yao N, Xie J, Zhang D, Zhang J, Zhang $X, Y e$ W. Two New Flavonoids from the Nuts of Areca catechu. Molecules. 2019 Aug 7;24(16):2862.

12. Peng $W$, Liu YJ, Wu N, Sun T, He XY, Gao YX, Wu CJ. Areca catechu L. (Arecaceae): a review of its traditional uses, botany, phytochemistry, pharmacology and toxicology. J Ethnopharmacol. 2015 Apr 22;164:340-56.

13. Patil PR, Rakesh SU, Dhabale PN, Burade KB. Pharmacological activities of Areca catechu Linn. A Review. J Phar Res. 2009;2(4):683-687. 
14. Pithayanukul P, Nithitanakool S, Bavovada R. Hepatoprotective potential of extracts from seeds of Areca catechu and nutgalls of Quercus infectoria. Molecules. 2009 Dec 1;14(12):4987-5000.

15. Boutaoui N, Zaiter L, Benayache F, Benayache S, Carradori S, Cesa S, Giusti AM, Campestre C, Menghini L, Innosa D, Locatelli M. Qualitative and Quantitative Phytochemical Analysis of Different Extracts from Thymus algeriensis Aerial Parts. Molecules. 2018 Feb 20;23(2):463.

16. Dar A, Khatoon S. Behavioral and Biochemical Studies of Dichloromethane Fraction from the Areca catechu Nut. Pharmacology Biochemistry and Behavior. Elsevier BV; 2000 Jan;65(1):1-6.

17. Kumar B, Kuhad A, Chopra K. Neuropsychopharmacological effect of sesamol in unpredictable chronic mild stress model of depression: behavioral and biochemical evidences. Psychopharmacology (Berl). 2011 Apr;214(4):819-28.

18. Willner P. The chronic mild stress (CMS) model of depression: History, evaluation and usage. Neurobiol Stress. 2016 Aug 24;6:78-93.

19. Grippo AJ, Na ES, Johnson RF, Beltz TG, Johnson AK. Sucrose ingestion elicits reduced Fos expression in the nucleus accumbens of anhedonic rats. Brain Res. 2004 Sep 3;1019(1-2):259-64.

20. Dhingra D, Sharma A. Evaluation of Antidepressant-like activity of glycyrrhizin in mice. Indin J Pharmacol. 2005;37:390-4.

21. Silverman JL, Yang M, Lord C, Crawley JN. Behavioural phenotyping assays for mouse models of autism. Nat Rev Neurosci. 2010 Jul;11(7):490502.

22. Gupta G, Jia Jia T, Yee Woon L, Kumar Chellappan D, Candasamy M, Dua K. Pharmacological Evaluation of Antidepressant-Like Effect of Genistein and Its Combination with Amitriptyline: An Acute and Chronic Study. Adv Pharmacol Sci. 2015:164943.

23. Ohkawa H, Ohishi N, Yagi K. Assay for lipid peroxides in animal tissues by thiobarbituric acid reaction. Anal Biochem. 1979 Jun;95(2):351-8.

24. Davidson B, Hird F. The estimation of glutathione in rat tissues. A comparison of a new spectrophotometric method with the glyoxalase method. Biochemical Journal. Portland Press Ltd.; 1964 Nov 1;93(2):232-236.

25. Bhosale U, Yegnanarayan R, Prachi P, Zambare M, Somani RS. Study of CNS depressant and behavioral activity of an ethanol extract of Achyranthes Aspera (Chirchita) in mouse model.
Ann Neurosci. 2011 Apr;18(2):44-7.

26. Willner P. Validity, reliability and utility of the chronic mild stress model of depression: a 10-year review and evaluation. Psychopharmacology (Berl). 1997 Dec;134(4):319-29.

27. Horenstein NA, Quadri M, Stokes C, Shoaib M, Papke RL. Cracking the Betel Nut: Cholinergic Activity of Areca Alkaloids and Related Compounds. Nicotine Tob Res. 2019 May 21;21(6):805-812.

28. Mahesh R, Bhatt S, Devadoss T, Jindal A, Gautam B, Pandey D. Antidepressant Potential of 5-HT3 Receptor Antagonist, N-n- propyl-3ethoxyquinoxaline-2-carboxamide (6n). J Young Pharm. 2012 0ct;4(4):235-44.

29. Bekris S, Antoniou K, Daskas S, PapadopoulouDaifoti Z. Behavioural and neurochemical effects induced by chronic mild stress applied to two different rat strains. Behav Brain Res. 2005 Jun 3;161(1):45-59.

30. Casarotto PC, Andreatini R. Repeated paroxetine treatment reverses anhedonia induced in rats by chronic mild stress or dexamethasone. Eur Neuropsychopharmacol. 2007 Nov;17(11):735-42.

31. Gourley SL, Taylor JR. Recapitulation and reversal of a persistent depression-like syndrome in rodents. Curr Protoc Neurosci. 2009 Oct;Chapter 9:Unit 9.32.

32. Bhutani MK, Bishnoi M, Kulkarni SK. Antidepressant like effect of curcumin and its combination with piperine in unpredictable chronic stress-induced behavioral, biochemical and neurochemical changes. Pharmacol Biochem Behav. 2009 Mar;92(1):39-43.

33. Bende M, Dudhgaonkar S, Jagdhani R, Bachewar N. The antidepressant like action of ethanolic extract of areca catechu on behavioral models of depression in rats. Int $\mathrm{J}$ Basic Clin Pharmacol. Medip Academy. 2016:2098-2102.

34. Bilici M, Efe H, Köroğlu MA, Uydu HA, Bekaroğlu M, Değer 0. Antioxidative enzyme activities and lipid peroxidation in major depression: alterations by antidepressant treatments. J Affect Disord. 2001 Apr;64(1):43-51.

35. Khanzode SD, Dakhale GN, Khanzode SS, Saoji A, Palasodkar R. Oxidative damage and major depression: the potential antioxidant action of selective serotonin re-uptake inhibitors. Redox Rep. 2003;8(6):365-70.

36. Maes M, De Vos N, Pioli R, Demedts P, Wauters A, 
Neels H, Christophe A. Lower serum vitamin E concentrations in major depression. Another marker of lowered antioxidant defenses in that illness. J Affect Disord. 2000 Jun;58(3):241-6.

37. Zhao Z, Wang W, Guo H, Zhou D. Antidepressantlike effect of liquiritin from Glycyrrhiza uralensis in chronic variable stress induced depression model rats. Behav Brain Res. 2008 Dec 1;194(1):108-13.

38. Chhillar R, Dhingra D. Antidepressant-like activity of gallic acid in mice subjected to unpredictable chronic mild stress. Fundam Clin Pharmacol. 2013 Aug;27(4):409-18.

39. Ng F, Berk M, Dean O, Bush AI. Oxidative stress in psychiatric disorders: evidence base and therapeutic implications. Int J Neuropsychopharmacol. 2008 Sep;11(6):851-76.

40. Zhang L, Luo J, Zhang M, Yao W, Ma X, Yu SY. Effects of curcumin on chronic, unpredictable, mild, stress- induced depressive-like behaviour and structural plasticity in the lateral amygdala of rats. Int J Neuropsychopharmacol. 2014 May;17(5):793-806.

41. Chen YP, Wang C, Xu JP. Chronic unpredictable mild stress induced depression-like behaviours and glutamate-glutamine cycling dysfunctions in both blood and brain of mice. Pharm Biol. 2019 Dec;57(1):280-286.

42. Kudryashov NV, Kalinina TS, Voronina TA. [Unpredictable chronic mild stress effects on antidepressants activities in forced swim test]. Ross Fiziol Zh Im I M Sechenova. 2015 Feb;101(2):163-70. Russian.

43. Ramanathan M, Balaji B, Justin A. Behavioural and neurochemical evaluation of Perment an herbal formulation in chronic unpredictable mild stress induced depressive model. Indian J Exp Biol. 2011 Apr;49(4):269-75.

Cite the Article as: Goud UK, Hasanthi K, Pandiri K, Manipriya K. Neuropharmacological Evaluation of Areca catechu on Chronic Unpredictable Mild Stress Model of Depression in Mice: Behavioral and Biochemical Evidences. J Drug Vigil Altern Ther. 2021 June 30;1(2):37-45.

\section{www.jdvat.org}

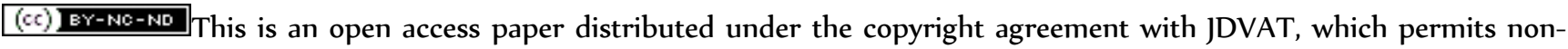
commercial unrestricted use, distribution, and reproduction in any medium or format, provided the original work is properly cited. 